\title{
Short-term Preemergence Herbicide Adsorption by Mulch Materials and Impacts on Weed Control
}

\author{
Debalina Saha ${ }^{1}$, S. Christopher Marble ${ }^{2}$, Brian Pearson ${ }^{2}$, \\ Héctor Pérez ${ }^{3}$, Gregory MacDonald ${ }^{3}$, and D. Calvin Odero ${ }^{4}$
}

AdDITIONAL INDEX WORDs. crabgrass, eclipta, ornamentals, pine bark, pine straw, spurge

SUMMARY. The objective of this research was to determine how mulch type affects adsorption and efficacy of commonly used preemergence herbicides in nurseries and landscapes. Nursery containers were filled with standard potting media and mulched with either pine bark (PB) mini-nuggets (mixed Pinussp.), pine straw (PS; mixed Pinus sp.), or shredded eucalyptus hardwood (HW; Eucalyptus sp.) at a 2inch depth. Herbicides including dimethenamid-P + pendimethalin (applied as a tank mix), prodiamine, and indaziflam were applied to mulched containers, watered in, and the mulch was subsequently removed 3 days later. Seeds of garden spurge (Euphorbia birta), large crabgrass (Digitaria sanguinalis), and eclipta (Eclipta prostrata) were then seeded and used as bioassay species for dimethenamid$\mathbf{P}+$ pendimethalin, prodiamine, and indaziflam, respectively. Chemical assays were also performed using a separate set of pots mulched with $\mathrm{PB}$ at 2 inches and treated with the same herbicides. Results from the bioassay experiment showed PS was the only mulch type that did not significantly decrease efficacy of any applied herbicide. Chemical assays showed only $34 \%$ of the applied dimethenamid-P reached the soil surface as evidenced by chemical assay, but more dimethenamid-P moved through PB than did pendimethalin $(12 \%)$ or prodiamine $(17 \%)$, which adsorbed more strongly. Overall results suggest preemergence herbicides will be strongly adsorbed to organic mulch. However, as mulch is typically more effective on weeds that germinate below the mulch layer, this does not automatically result in reduced efficacy from herbicide + mulch combinations, and the addition of a preemergence herbicide may be effective in reducing weed germination within or on top of the mulch layer.

$\mathrm{M}$ ulching is one of the most widely adopted and effective methods of weed control in landscape planting beds (Chalker-Scott, 2007; Marble et al., 2015a). Although mulch is an effective weed management tool, preemergence herbicides may be used in combination with mulch to reduce labor costs associated with hand weeding, repeated application of postemergence herbicides, or both

Received for publication 12 June 2019. Accepted for publication 3 Sept. 2019.

Published online 1 November 2019

${ }^{1}$ Michigan State University, East Lansing, MI 48224

${ }^{2}$ University of Florida, Mid-Florida Research and Education Center, Apopka, FL 32703

${ }^{3}$ University of Florida, Gainesville, FL 32611

${ }^{4}$ University of Florida, Everglades Research and Education Center, Belle Glade, FL 33430

S.C.M. is the corresponding author. E-mail: marblesc@ ufl.edu.

This is an open access article distributed under the CC BY-NC-ND license (https://creativecommons.org/ licenses/by-nc-nd $/ 4.0 /$ )

https://doi.org/10.21273/HORTTECH04432-19
(Marble, 2015; Marble et al., 2015a, 2015b; Wilen and Elmore, 2007). In addition to weed control benefits, use of common mulch, such as PB or PS, has been shown to reduce runoff and leaching of preemergence herbicides, including pendimethalin, metolachlor, and isoxaben, by $35 \%$ to $74 \%$ in the landscape compared with application of these herbicides to bare soil
(Knight et al., 2001). Container nurseries also may use various mulch materials for weed control (Case et al., 2002). Addition of mulch as part of an overall integrated weed management program could reduce the number of herbicide applications needed, improve weed control and crop safety when using preemergence herbicides, and could potentially reduce runoff or leaching of preemergence herbicides (Bartley et al., 2017; Mathers and Ozkan, 2001; Wilson et al., 1996).

In general, wood products, PB, and other plant residues have a high sorption capacity for many herbicides (Brás et al., 1999; Huang et al., 2006). Herbicide sorption to organic mulch is dependent upon herbicide properties, namely solubility and soil adsorption coefficient $\left[\mathrm{K}_{\mathrm{oc}}\right.$ (Aslam et al., 2013; Senseman, 2007; Weber, 1990)]. In addition to herbicide properties, herbicide adsorption will be influenced by the chemical and physical composition of mulch or plant residues, which are dependent on material age or stage of decomposition, the origin of the material, and the particle size or surface area (Ahmad et al., 2001; Aslam et al., 2013; Benoit et al., 2008; Dao, 1991).

There have been few studies focusing on sorption of preemergence herbicides used in ornamentals with common landscape or nursery mulch materials. In field crops, increasing levels of plant residue on the soil surface in conservation tillage systems have been reported to cause reductions in herbicide efficacy due to herbicide adsorption (Buhler, 1992). Mulch or residue materials usually decrease efficacy by binding the herbicide and inhibiting it from reaching the soil surface or by increasing

\begin{tabular}{llll}
\hline $\begin{array}{l}\text { Units } \\
\begin{array}{l}\text { To convert U.S. to SI, } \\
\text { multiply by }\end{array}\end{array}$ & U.S. unit & SI unit & $\begin{array}{l}\text { To convert SI to U.S., } \\
\text { multiply by }\end{array}$ \\
\hline 1.0432 & $\mathrm{fl} \mathrm{oz} / \mathrm{oz}$ & $\mathrm{mL} \cdot \mathrm{g}^{-1}$ & 0.9586 \\
0.0929 & $\mathrm{ft}^{2}$ & $\mathrm{~m}^{2}$ & 10.7639 \\
3.7854 & $\mathrm{gal}$ & $\mathrm{L}$ & 0.2642 \\
9.3540 & gal $/ \mathrm{acre}$ & $\mathrm{L} \cdot \mathrm{ha}^{-1}$ & 0.1069 \\
2.54 & inch $(\mathrm{es})$ & $\mathrm{cm}$ & 0.3937 \\
25.4 & inch $(\mathrm{es})$ & $\mathrm{mm}$ & 0.0394 \\
6.4516 & inch & $\mathrm{cm}^{2}$ & 0.1550 \\
1.1209 & $\mathrm{lb} / \mathrm{acre}^{2}$ & $\mathrm{~kg} \cdot \mathrm{ha}^{-1}$ & 0.8922 \\
0.0160 & $\mathrm{lb} / \mathrm{ft}^{3}$ & $\mathrm{~g} \cdot \mathrm{cm}^{-3}$ & 62.4274 \\
0.5933 & $\mathrm{lb} / \mathrm{yard}$ & $\mathrm{kg} \cdot \mathrm{m}^{-3}$ & 1.6856 \\
28.3495 & $\mathrm{oz}$ & $\mathrm{g}$ & 0.0353 \\
28,350 & $\mathrm{oz}$ & $\mathrm{mg}$ & $3.5274 \times 10^{-5}$ \\
1 & $\mathrm{ppm}$ & $\mathrm{mg} \cdot \mathrm{L}^{-1}$ & 1 \\
6.8948 & $\mathrm{psi}$ & $\mathrm{kPa}$ & 0.1450 \\
$\left({ }^{\circ} \mathrm{F}-32\right) \div 1.8$ & ${ }^{\circ} \mathrm{F}$ & ${ }^{\circ} \mathrm{C}$ & $\left({ }^{\circ} \mathrm{C} \times 1.8\right)+32$ \\
& & & \\
\hline
\end{tabular}

Hortlechnology · December 2019 29(6) 
microbial activity and thereby increasing the speed of herbicide degradation (Banks and Robinson, 1986; Chauhan and Abugho, 2012; Locke and Bryson, 1997). Banks and Robinson (1984) studied the effects of oryzalin applied to straw-covered and nonmulched soils. The amount of oryzalin reaching the soil surface was reduced in the presence of straw at the time of herbicide application, and the oryzalin concentration in the soil declined as the amount of straw increased. Similar results have been reported with pendimethalin and oxadiazon when applied to soils mulched with rice (Oryza sativa) residues (Chauhan and Abugho, 2012).

In contrast, Crutchfield et al. (1986) investigated the effects of metolachlor when applied to wheat (Triticum sp.) straw mulch and reported that although soil concentrations of metolachlor were significantly lower when applied in the presence mulch, weed control increased with increasing mulch level due to the weed suppression ability of the mulch. In ornamental production, synergistic herbicide and mulch interactions have been reported, as mulch may act as a slow-release herbicide carrier, extending the longevity of weed control, or provide control of weeds when mulch alone or mulch depth is insufficient (Case et al., 2002; Mathers and Case, 2010; Saha et al., 2019). However, observed synergism with herbicides and mulch typically results when mulch is applied at an adequate depth, usually more than 2 inches (Marble, 2015). Herbicide degradation will occur more rapidly than mulch degradation, and after several months, the type and depth of mulch will be the most important factors in terms of weed suppression if sequential herbicide applications are not made (Bartley et al., 2017).

It has been established that significant herbicide adsorption can occur when applied to mulched soils, but impacts on efficacy may or may not occur depending on mulch depth and the weed species evaluated (Banks and Robinson, 1984; Chauhan and Abugho, 2012; Crutchfield et al., 1986). Most of the research on herbicide adsorption to mulch has focused on no-till situations that are not applicable in most nursery or landscape environments for several reasons. First, in container ornamentals or landscapes, mulch is often not applied at recommended depths of 2 to 3 inches (Chalker-Scott, 2007). This commonly occurs in nurseries, as containers are completely filled with potting media, and depths of 2 to 3 inches may be cost prohibitive or difficult in large landscapes. As many common landscape and container weed species can emerge through mulch depths of 2 inches or more, herbicide adsorption could decrease control if depths of 2 inches or less are used (Richardson et al., 2008; Saha et al., 2019; Teasdale and Mohler, 2000). Second, mulch is often lost in container plants from blow over during weather events or moving containers during normal operations. Consequently, significant adsorption could lead to poor weed control if mulch were removed from containers. Most research on mulch and herbicide use in ornamentals has focused on long-term efficacy of various mulchherbicide combinations (Bartley et al., 2017; Case et al., 2005; Mathers and Case, 2010; Saha et al., 2019). For landscapes and nursery scenarios, it is unknown how much herbicide is immediately adsorbed or intercepted by mulch or how efficacy would be affected if mulch levels were not sufficient for weed control or if mulch was lost soon after application. Therefore, the objective of this research was to assess adsorption of preemergence herbicides to mulches commonly used in nurseries and landscapes using short-term bioassay and chemical assay experiments conducted soon after herbicide application.

\section{Materials and methods}

C ONTA IN E R B I OAS S A Y EXPERIMENTS. Research was conducted at the Mid-Florida Research and Education Center, Apopka, FL, in Summer 2018. Plastic nursery containers $(5.5$ inches width $\times 5.5$ inches height with $1.7 \mathrm{~L}$ volume) were filled with a PB:peat substrate (Fafard52 growing mix; Sun Gro Horticulture, Agawam, MA) amended with $10 \mathrm{lb} /$ yard $^{3} 15 \mathrm{~N}-3.9 \mathrm{P}-9.9 \mathrm{~K}$ controlledrelease fertilizer (Osmocote Plus; Everris, Geldermalsen, The Netherlands) based on the manufacturer's recommended medium rate for incorporation. PS (Pine Straw of Central Florida, Winter Garden, FL), PB mini-nuggets (Timberline Old Castle Lawn \& Garden Inc., Atlanta, GA), or shredded eucalyptus HW mulch (Florida Select Natural Eucalyptus Mulch; Scotts, Marysville, $\mathrm{OH}$ ) were then applied at a depth of 2 inches on top of each container. Herbicides chosen for evaluation included indaziflam (Marengo 0.622 SC; Bayer Crop Science, Research Triangle Park, NC), prodiamine (Barricade 4 FL; Syngenta Crop Protection, Greensboro, NC), and dimethenamid$\mathrm{P}+$ pendimethalin (Tower $6 \mathrm{EC}+$ Pendulum 3.3 EC; BASF Corp., Research Triangle Park, NC). Herbicides were chosen because they are commonly used in both landscape beds and in nurseries and represent three commonly used herbicide mechanisms of action used in and around ornamental plants in Florida (Neal et al., 2017). These herbicides and mulch types also have been evaluated previously for weed efficacy, both when in combination and when used individually over a longer-term study (Saha et al., 2019). Indaziflam, prodiamine, and dimethenamid-P + pendimethalin were applied at labeled rates $(0.04,1.5$, and $1.5+2.0$ $\mathrm{lb} / \mathrm{acre}$, respectively) to mulched containers using a carbon dioxide backpack sprayer (Bellspray; R\&D Sprayers, Opelousas, LA) calibrated to deliver $20 \mathrm{gal} / \mathrm{acre}$ using a flat-fan nozzle tip (8004; TeeJet Technologies, Wheaton, IL) at 30 psi on 6 June 2018 (run 1) and 12 July 2018 (run 2 ). Two separate groups of controls were maintained for comparison. First, a nonmulched herbicide control was included that was treated with aforementioned herbicides but was not mulched at the time of application. A nonmulched, nonherbicidetreated control was also maintained for comparison. Following treatment, all containers were placed on an outdoor nursery pad.

Although reports with indaziflam and prodiamine are lacking, downward leaching of up to $9 \mathrm{~cm}$ has been reported with pendimethalin and dimethenamid-P in PB substrates following 1 -inch of irrigation applied daily for $7 \mathrm{~d}$ (Derr et al., 2015; Robertson and Derr, 2017; Simmons and Derr, 2007). Therefore in the present study, only 0.5 inch of irrigation was applied per day over only $3 \mathrm{~d}$ ( 1.5 inches total) with the aim of minimizing leaching in the potting substrate while also allowing for proper incorporation of herbicides 
(required irrigation volumes of 0.25 to 0.5 inch) based on manufacturer recommendations for all four herbicides. Following irrigation and at $3 \mathrm{~d}$ after herbicide treatment, mulch was carefully removed from each pot using forceps so that only the herbicide reaching the substrate surface was available for weed control and the presence of mulch did not confound results. Following mulch removal, 20 seeds of either eclipta, large crabgrass, or garden spurge were surface sown to the previously mulched pots and used as bioassay species to assess herbicide adsorption to mulch. Eclipta was used for indaziflam, large crabgrass for prodiamine, and garden spurge for dimethenamid-P + pendimethalin. These weed species were chosen because they are problematic in nurseries and landscapes in Florida and have previously shown a high degree of sensitivity to the aforementioned herbicides (Neal et al., 2017; Saha et al., 2019). The experiment was a completely randomized design with six single pot replicates per herbicide and mulch combination and the nontreated, nonmulched control group. This resulted in five total treatments for each weed species, including each mulch type (HW, PB, or PS) with herbicide, a herbicide-only control, and the nonmulched, nontreated control.

Data collection included weed counts at 2 and 4 weeks after treatment (WAT). At 4 WAT, all weed species were cut at the soil line and shoot fresh weights were determined. All data were subjected to a mixed model analysis of variance (ANOVA) after meeting the assumptions of normality using SAS (version 9.4; SAS Institute, Cary, NC). Mulch types were fixed effects and the different experimental runs and replication were random effects. All data were subjected to a mixed model ANOVA after meeting the assumptions of normality using SAS (version 9.4). Mulch types were fixed effects and the different experimental runs and replication were random effects. Fisher's protected least significance difference test was used to compare means of experimental variables. All differences were considered significant at $P \leq$ 0.05 and each weed species was analyzed separately.

Chemical assay EXPERIMENT. In addition to the bioassay described previously, chemical assays were performed to estimate herbicide adsorption to $\mathrm{PB}$ mulch. PB mulch was chosen for these experiments because it is one of the most commonly used mulch materials used in both container nurseries and in landscapes in Florida. Round plastic nursery containers ( 10 inches diameter $\times 5$ inches height) were filled with substrate and amendments as previously described. PB mulch was then applied at a depth of 2 inches on top of each container. A nonmulched control was also included for comparison of herbicide concentration in the substrate with and without mulch at the time of application. Commercially available liquid formulations of indaziflam, prodiamine, and dimethenamid-P + pendimethalin were applied as described previously, and pots were irrigated in the same manner as the bioassay experiment. Following treatment and 1.5 inches of irrigation, mulch was removed carefully with forceps without disturbing the underlying substrate as described previously.

Following mulch removal and irrigation, the substrate beneath the PB mulch was sampled to a depth of 1 inch from each container for herbicide quantification using a metal spatula. A total volume of $0.82 \mathrm{~L}$ of potting substrate was collected from each container but the PB mulch was not analyzed. Quantification of each herbicide in the substrate underneath mulch was determined using previously described methods [U.S. Environmental Protection Agency (USEPA), 2016, 2018a, 2018b]. Briefly, after collection, samples were placed in paper bags and stored in a walk-in cooler maintained at $4{ }^{\circ} \mathrm{C}$ until analysis. Before chemical analysis, substrate samples were transferred from the cooler and allowed to air dry at room temperature. The Soxhlet extraction procedure was used for herbicide extraction on substrate samples (USEPA, 2016). Samples were mixed with anhydrous sodium sulfate and extracted using acetone:hexane (1:1 by volume) as solvent in a Soxhlet extractor. Reverse-phase high-performance liquid chromatographic (RP/HPLC) and thermospray (TS) mass spectrometric (MS) conditions were used for the detection of the indaziflam. Sample extracts were analyzed by direct injection (100 $\mu \mathrm{L}$ volume of sample) onto a liquid chromatographic-TS interface. A gradient elution program was used on the liquid chromatograph to separate the compounds. Quantitative analysis was performed by TS/MS detection (USEPA, 2018b). For the detection of dimethenamid$\mathrm{P}$, pendimethalin, and prodiamine herbicides from the substrate extract, gas chromatography (GC)/MS was used. The sample extracts were injected into a GC equipped with a narrow-bore fused-silica capillary column. Identification of the target analyte (dimethenamid-P, pendimethalin, or prodiamine) was accomplished by comparing their mass spectra and retention times with the mass spectra and retention times of known standards. Quantification was accomplished by comparing the response of a major (quantitation) ion relative to an internal standard using calibration curves (USEPA, 2018a). All herbicide quantification data were converted to percent retention by $\mathrm{PB}$ mulch by using the formula $\{[$ (nonmulched mulched) $/$ nonmulched] $\times 100\}$. The experiment was organized as a completely randomized design following treatment with three single pot replications per treatment as described in in the bioassay experiment. Data were arcsine square root transformed before analysis to meet the assumptions of ANOVA and subsequently analyzed as previously described. Untransformed data are reported to retain biological meaning.

Mulch PHysical PROPERTY ANALYSIS. Physical analysis included particle size distribution, bulk density, and volumetric calculations to determine percentages of air, water, and solid in a given volume of mulch. Average mulch surface area was also estimated for mulch particles and on a volume basis. All analyses were determined in laboratory settings at the Mid-Florida Research and Education Center and were repeated in time using four replicates per mulch type for each experimental run. Mulch samples were spread into a single layer in the laboratory and allowed to air dry before all analysis.

Particle size distribution was determined by placing four 100-g samples of mulch through a series of U.S. standard soil sieves (WS Tyler, Mentor, $\mathrm{OH}$ ) ranging from $50 \mathrm{~mm}$ to less than $2 \mathrm{~mm}$. Sieves were stacked in descending order, placed in a mechanized sieve 
shaker (model no. SS-15; Gilson Co., Lewis Center, $\mathrm{OH}$ ) for $5 \mathrm{~min}$, and then mulch in each size was weighed and recorded. Bulk density was determined by lightly packing mulch samples into a box (12 inches width $\times$ 12 inches width $\times 12$ inches height). Materials were lightly packed by dropping a perforated metal plat $(750 \mathrm{~g}$ weight) five times from a height of 2 inches above the mulch surface (Crown et al., 2013). After mulch was packed, dry weight was recorded. In bioassay experiments described previously, mulch was added based on volume but weight was estimated by multiplying bulk density by the volume of mulch in each container.

Volumetric calculations for air, water, and solid space for each mulch in a given volume were completed for each mulch on a percentage basis using previously described procedures with some modification (Akdeniz et al., 2011; Powrie, 2014; Simmons and Derr, 2007). Mulch materials were lightly packed inside 2.2-L containers and dry weights were recorded. Containers were then placed inside a water bath with a water level equal to the mulch level in the container. Each mulch-filled container was covered in plastic wrap and covered with a weighted plastic tray to prevent evaporation and mulch floating. Containers were allowed to saturate for $24 \mathrm{~h}$ so that all macropore (air space in between mulch particles) and micropore (water absorbed inside mulch particles) space was filled with water. After $24 \mathrm{~h}$, containers were drained until all dripping ceased and water from each container was recorded (air space or macropore space). Containers were then weighed again to determine amount of water absorbed by mulch (water space or micropore space). Percent air in each container was calculated by dividing volume of water that dripped from the container by the container volume. Percent water was calculating by dividing the difference between mulch wet weight and mulch dry weight by the container volume. The remaining percentage represented the percentage of solid material in each container.

Mulch materials are generally composed of a wide range of particles with different sizes that change over time as materials degrade (Duryea et al., 1999). Therefore, average surface area was estimated for both representative samples using weight and for individual particles. In both cases, mulch surface area was determined using Image J software (National Institutes of Health, Bethesda, MD) (Schneider et al., 2012). To determine surface area using mulch weight, a white corrugated plastic board was cut into a $1-\mathrm{m}^{2}$ square section and $100 \mathrm{~g}$ mulch samples were spread evenly into a single layer over the sheet, ensuring that no particles were overlapping. Photos were taken using a digital camera (model D3400; Nikon, Tokyo, Japan) at a height of $5 \mathrm{ft}$ directly over the sheet using a custom-built frame so that all images were taken from the same height and location relative to the plastic board. Images were then analyzed in ImageJ using the threshold option. This gave a percentage of the plastic sheet $\left(1 \mathrm{~m}^{2}\right)$ covered with each 100-g sample of mulch. Surface area for $1 \mathrm{~g}$ of mulch was calculated by dividing surface area by 100 . Average surface area for individual particles was accomplished using the soil-sieving method described previously. First, the percentage of each 100-g sample was determined for each sieve size as described previously. Percentages were then divided by 10 , rounded to whole numbers, and then used to determine how many particles from each screen size to select for surface area determination. For example, if $32.4 \mathrm{~g}$ of $\mathrm{PB}$ was collected in the $12.5-\mathrm{mm}$ sieve, three individual particles were randomly selected from that sieve. Particles that could not be positively identified as either $\mathrm{HW}, \mathrm{PB}$, or PS (e.g., very small particles) were excluded from analysis. Total surface area was determined using ImageJ and then divided by the number of individual particles in each image to calculate average surface area of an individual mulch particle. All physical property analyses were analyzed statistically as previously described.

\section{Results and discussion}

C O N T A I N R B I OAS S A Y EXPERIMENTS. Garden spurge counts at 2 WAT showed that HW was the only mulch material that significantly reduced dimethenamid-P + pendimethalin efficacy in relation to nonmulched pots (Table 1). At 4 WAT, similar results were observed, but at this evaluation timing, PS was the only mulch material that did not significantly reduce weed counts in relation to the nonmulch pots. The combination of dimethenamid-P + pendimethalin provided similar control of garden spurge when it was applied to the nonmulched substrate and pots originally mulched with PS, with both treatments resulting in $100 \%$ control. Pots that were originally mulched with either $\mathrm{HW}$ or $\mathrm{PB}$ provided commercially acceptable control (96\% control), but to a lower degree than was observed in nonmulched pots or pots originally mulched with PS.

Similar to results observed with garden spurge and dimethenamid-P + pendimethalin, PS was the only mulch material that did not significantly reduce efficacy of indaziflam at 2 WAT or 4 WAT based on eclipta counts. When indaziflam was applied to pots initially mulched with $\mathrm{PB}$ ( $88 \%$ reduction in counts) and PS (99\% reduction in counts), eclipta counts was similar to that of nonmulched pots $(100 \%$ reduction in counts), indicating that these two mulch types had no detrimental effect on indaziflam efficacy of eclipta (Table 1). Only $72 \%$ reduction in eclipta counts was observed in pots originally mulched with $\mathrm{HW}$, which indicates that indaziflam was more tightly bound to this mulch, or was adsorbed to a greater degree with HW compared with PB or PS.

At 2 WAT, all mulch materials resulted in reduced efficacy of prodiamine based on large crabgrass counts. Large crabgrass counts ranged from 1.3 to 1.5 per pot, equivalent to a $55 \%$ to $61 \%$ reduction in based on the nontreated, nonmulched pots, whereas a $97 \%$ reduction was observed in pots that were treated with prodiamine but were not mulched. Large crabgrass fresh weight data showed that PB $(57 \%$ control) was the only mulch type that caused a significant reduction in prodiamine efficacy. Prodiamine provided a similar reduction in large crabgrass fresh weights when pots were originally mulched with HW or PS $(84 \%)$ and when no mulch was present $(100 \%)$. Although a high degree of large crabgrass control was observed, it should be noted that germination was less than expected. Although spotted spurge and eclipta germination averaged $55 \%$ and $87 \%$ in 


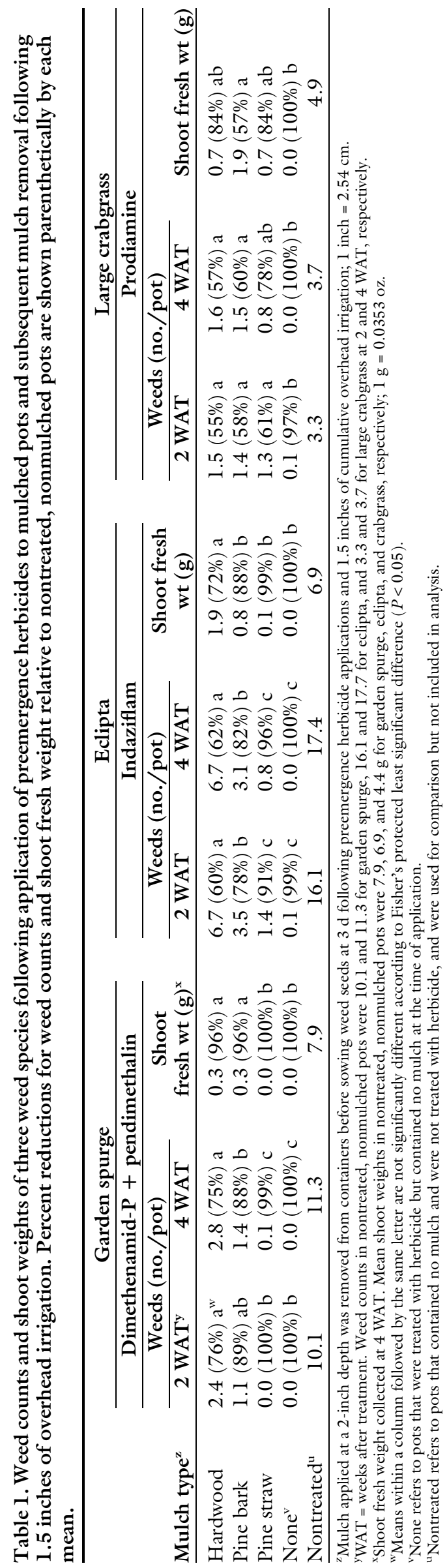

nontreated controls, respectively, large crabgrass germination was low and only $19 \%$ germination was observed in nonmulched, nontreated controls (Table 1). However, as germination was close to $20 \%$ and was consistent at this level in nontreated controls, it is likely these data still provide a suitable demonstration of prodiamine adsorption in a nursery or landscape environment. However, it is possible that large crabgrass control would be lower than reported here if higher weed pressure was present.

Chemical assay eXPeriments. PB retained pendimethalin $(88 \%)$ and prodiamine $(83 \%)$ to a greater degree than dimethenamid-P $(66 \%)$ as evidenced by chemical assays of the substrate beneath the mulch layer (Table 2). Only $12 \%$ and $17 \%$ of the applied pendimethalin and prodiamine reached the underlying substrate surface, whereas $34 \%$ of the applied dimethenamid-P was recovered in the substrate. This result was similar to previous findings following a pendimethalin application to sugarcane (Saccharum sp.) mulch residue (Selim et al., 2003). Selim et al. (2003) reported up to a $50 \%$ reduction in pendimethalin concentration in soils in which sugarcane residue was left on the soil surface following harvest. Similar results have been reported with switchgrass (Panicum virgatum) residues (Mersie et al., 2006). More than $80 \%$ retention was observed in our study, likely due to the higher mulch level present (2 inches). Both pendimethalin and prodiamine have comparatively low solubility values and high adsorption coefficients $\left(\mathrm{K}_{\mathrm{oc}}\right)$, and are not prone to leaching and are generally tightly bound to organic particles, such as a $\mathrm{PB}$ mulch (Table 2) (Senseman, 2007; USEPA, 2010). Conversely, dimethenamid-P is characterized as having a higher likelihood of leaching due to greater solubility and lower $\mathrm{K}_{\mathrm{oc}}$. Pendimethalin and prodiamine leaching have been shown to be minimal in $\mathrm{PB}$ substrates (Simmons and Derr, 2007; Stewart et al., 2019). However, a greater void space in a mulch material compared with the previous studies with $\mathrm{PB}$ growing substrate is likely to cause more downward movement (Simmons and Derr, 2007 ), leading to a recovery of $12 \%$ 
to $17 \%$ through the mulch layer. At similar to the other herbicides evaluated. Indaziflam movement through a PB mulch or PB substrate have not been previously reported, but leaching in a fine Candler sand soil in Florida has been reported to be limited under simulated high rainfall due to the relatively low solubility characteristics of indaziflam (Jhala and Singh, 2012).

Physical property analysis. Particle size analysis showed that PS was mostly composed of particles larger than $50 \mathrm{~mm}(\mathbf{5 7 . 7} \%)$, whereas $\mathrm{PB}$ was mostly composed of particles ranging from 25 to $6.3 \mathrm{~mm}$ (Table 3 ). HW mulch tended to have a greater percentage of smaller particles compared with PB or PS with most particles ranging from $6.3 \mathrm{~mm}$ to less than $2 \mathrm{~mm}$. PB had the highest bulk density of any mulch $\left(0.18 \mathrm{~g} \cdot \mathrm{cm}^{-3}\right)$ followed by HW $\left(0.09 \mathrm{~g} \cdot \mathrm{cm}^{-3}\right)$ and PS $\left(0.04 \mathrm{~g} \cdot \mathrm{cm}^{-3}\right)$. Surface area calculations showed that although individual PB particles had a larger surface area for individual particles, a higher bulk density resulted in a lower surface area value for $\mathrm{PB}$ compared with HW or PS when examining surface $77 \%$ retention by $\mathrm{PB}$, indaziflam was

area on a mulch weight basis (Table 4 ). Void space within the three mulch types showed that a layer of PS contained a higher percentage of air space (85\%) compared with HW (67\%) or PB (58\%). Conversely, PS had the least amount of solid material (i.e., mulch) (9\%) compared with HW $(17 \%)$ or $\mathrm{PB}(30 \%)$. These data indicate that in a given mulch layer, PS contained the most air or void space, followed by HW and PB. PS (6\%) also absorbed less water than $\mathrm{PB}$, whereas HW absorbed the most.

Similar to previous findings (Johnson, 1997; Marble et al., 2011), herbicides evaluated in these experiments provided a high level of control of each bioassay weed species when applied to the substrate surface when no mulch was present at the time of application. When mulch was present during the application, results differed by herbicide and mulch material. PS was the only mulch material in which weed counts and fresh weights of the target weed species were consistently similar to the nonmulched control group. The only exception was with prodiamine and large crabgrass at 2 WAT, when large

Table 2. Retention of preemergence herbicides in 2 inches $(5.08 \mathrm{~cm})$ of pine bark mulch following 1.5 -inches $(3.81 \mathrm{~cm})$ of irrigation.

\begin{tabular}{lccc}
\hline Herbicide & Solubility $\left(\mathbf{m g} \cdot \mathbf{L}^{-\mathbf{l}}\right)^{\mathbf{z}}$ & $\mathbf{K}_{\mathrm{oc}}\left(\mathbf{m L} \cdot \mathbf{g}^{-\mathbf{1}}\right)^{\mathrm{y}}$ & ${\text { Retention }(\%)^{\mathrm{x}}}^{\mathrm{y}}$ \\
\hline Dimethenamid-P & $1174^{\mathrm{v}}$ & $55-125^{\mathrm{u}}$ & $66 \mathrm{~b}^{\mathrm{w}}$ \\
Indaziflam & 4.4 & 496 & $77 \mathrm{ab}$ \\
Pendimethalin & 0.275 & 17,200 & $88 \mathrm{a}$ \\
Prodiamine & 0.013 & 13,000 & $83 \mathrm{a}$ \\
\hline
\end{tabular}

${ }^{\mathrm{z}}$ Solubility values were derived from Senseman (2007) and U.S. Environmental Protection Agency (2010). Mean solubility values are given as solubility will be variable depending on temperature, $\mathrm{pH}$, and other factors; $1 \mathrm{mg} \cdot \mathrm{L}^{-1}=$ 1 ppm.

${ }^{{ }^{y}} K_{o c}=$ soil adsoprtion coefficient. Values were derived from Senseman (2007) and U.S. Environmental Protection Agency (2010). Mean $\mathrm{K}_{\mathrm{oc}}$ are given as adsoprtion and will be variable based on soil characteristics; $1 \mathrm{~mL} \cdot \mathrm{g}^{-1}=$ $0.9586 \mathrm{fl} \mathrm{oz} / \mathrm{oz}$.

${ }^{\mathrm{x}}$ Mean percentage of herbicide retained in mulch layer by comparing herbicide concentrations in soil from nonmulched pots with herbicide concentrations in soil from mulched pots. Dimethenamid-P, indaziflam, pendimethalin, and prodiamine were applied at rates of $1.5,0.04,2.0$, and $1.5 \mathrm{lb} /$ acre or $8.5,0.25,11.2$, and $8.5 \mathrm{mg} /$ pot, respectively; $1 \mathrm{lb} /$ acre $=1.1209 \mathrm{~kg} \cdot \mathrm{ha}^{-1}, 1 \mathrm{mg}=3.5272 \times 10^{-5} \mathrm{oz}$.

${ }^{w}$ Means followed by the same letter are not significantly different according to Fisher's protected least significant difference $(P<0.05)$.

Table 3. Particle size analysis of hardwood, pine bark, and pine straw mulch.

\begin{tabular}{lrrrrrrrr}
\hline & \multicolumn{7}{c}{ U.S. Standard soil sieve size $(\mathbf{m m})^{\mathrm{z}}$} \\
\cline { 2 - 9 } Mulch type & $\mathbf{5 0}$ & $\mathbf{2 5}$ & $\mathbf{1 9}$ & $\mathbf{1 2 . 5}$ & $\mathbf{6 . 3}$ & $\mathbf{3 . 3 5}$ & $\mathbf{2}$ & $<\mathbf{2}$ \\
\cline { 2 - 9 } & & & \multicolumn{7}{c}{ Mean retention by wt (\%) } \\
Hard wood & $0.0 \mathrm{~b}^{\mathrm{y}}$ & $1.6 \mathrm{~b}$ & $3.5 \mathrm{~b}$ & $10.6 \mathrm{~b}$ & $38.9 \mathrm{a}$ & $18.5 \mathrm{a}$ & $8.8 \mathrm{a}$ & $17.1 \mathrm{a}$ \\
Pine bark & $0.0 \mathrm{~b}$ & $15.7 \mathrm{a}$ & $23.2 \mathrm{a}$ & $28.1 \mathrm{a}$ & $26.8 \mathrm{~b}$ & $4.9 \mathrm{~b}$ & $0.4 \mathrm{~b}$ & $0.6 \mathrm{~b}$ \\
Pine straw & $57.7 \mathrm{a}$ & $2.0 \mathrm{~b}$ & $0.7 \mathrm{~b}$ & $2.3 \mathrm{c}$ & $4.4 \mathrm{c}$ & $8.0 \mathrm{~b}$ & $12.3 \mathrm{a}$ & $12.6 \mathrm{a}$ \\
\hline
\end{tabular}

${ }^{\mathrm{z}}$ Mulch was air-dried until reaching a constant weight and then four $100-\mathrm{g}(3.53 \mathrm{oz})$ samples were passed through sieves in descending order; $1 \mathrm{~mm}=0.0394$ inch.

${ }^{y}$ Means followed by the same letter within each sieve size are not significantly different according to Fisher's protected least significant difference $(P<0.05)$. crabgrass counts were significantly higher in all pots that initially contained mulch. PS did not cause any reductions in efficacy based on counts or shoot fresh weights at 4 WAT for any of the three weed and herbicide combinations evaluated. This indicates that the herbicides evaluated in this study likely adsorbed less to PS compared with HW or PB mulch.

Less interception by PS is likely attributable to a higher percentage of large particles compared with $\mathrm{PB}$ or HW and greater air or void space. Both HW and PB contained more small particles than did PS and had greater bulk densities, resulting in less solid mulch particles occupying the 2inch mulch layer in containers. A higher percentage of smaller particles present in $\mathrm{HW}$ and $\mathrm{PB}$ also provides more adsorption sites for herbicides, similar to previous reports with $\mathrm{PB}$ and other particulate organic matter (Benoit et al., 2008; Brás et al., 1999). Although the surface area of individual particles for $\mathrm{HW}$ and PS were similar, a 2-inch layer of HW would have more than twice the weight of a 2 -inch layer of PS and contain $67 \%$ air or void space compared with $85 \%$ air space for PS (Table 4).

Previous research has also shown that herbicide adsorption can be influenced by chemical composition. In wood- or plant-derived mulch materials, increased adsorption is associated with increased lignin content, whereas a higher percentage of cellulose often limits herbicide sorption (Benoit et al., 2008; Dao, 1991; Riggle and Penner, 1992). Reports of lignin and cellulose concentrations of $\mathrm{HW}, \mathrm{PB}$, and PS mulch show that generally, PS and HW have similar lignin $(30 \%$ to $38 \%)$ concentrations, that is, less than PB (45\%) (Table 5). Lignin has typically been shown to have high adsorption potential, thus it would be expected for PB would have a greater tendency to bind herbicides compared with HW or PS (Dao, 1991). Higher cellulose concentrations are also negatively correlated with herbicide adsorption, and both PS and HW also had higher cellulose concentration compared with $\mathrm{PB}$. Although lignin and cellulose concentrations were generally similar between HW and PS, lower bulk density and consequently greater air space and larger particle sizes associated with PS likely contributed 
Table 4. Mean bulk density, surface area, and volumetric calculations for hard wood, pine bark, and pine straw mulch.

\begin{tabular}{|c|c|c|c|c|c|c|c|}
\hline & \multicolumn{2}{|c|}{$\begin{array}{l}\text { Particle } \\
\text { density }^{z}\end{array}$} & \multicolumn{2}{|c|}{$\begin{array}{l}\text { Surface area } \\
\qquad\left(\mathrm{cm}^{2}\right)^{\mathrm{y}}\end{array}$} & \multicolumn{3}{|c|}{$\begin{array}{l}\text { Void space } \\
\qquad(\%)^{x}\end{array}$} \\
\hline & $\begin{array}{c}\text { Bulk density } \\
\left(\mathrm{g} \cdot \mathrm{cm}^{-3}\right)^{\mathrm{z}}\end{array}$ & $\begin{array}{l}\text { Mulch wt in } \\
\text { container }(\mathrm{g})^{\mathrm{z}}\end{array}$ & $\begin{array}{l}\text { by wt } \\
(1 \mathrm{~g})\end{array}$ & $\begin{array}{c}\text { by } \\
\text { particle }\end{array}$ & Air & Solid & Water \\
\hline Hardwood & $0.09 \mathrm{~b}^{\mathrm{w}}$ & $88.6 \mathrm{~b}$ & $27.6 \mathrm{a}$ & $3.0 \mathrm{~b}$ & $67 \mathrm{~b}$ & $17 \mathrm{~b}$ & $16 \mathrm{a}$ \\
\hline Pine bark & $0.18 \mathrm{a}$ & $179.9 \mathrm{a}$ & $6.8 \mathrm{~b}$ & $9.9 \mathrm{a}$ & $58 \mathrm{c}$ & $30 a$ & $12 \mathrm{~b}$ \\
\hline Pine straw & $0.04 \mathrm{c}$ & $36.3 c$ & $26.4 \mathrm{a}$ & $3.1 \mathrm{~b}$ & $85 \mathrm{a}$ & $9 \mathrm{c}$ & $6 c$ \\
\hline
\end{tabular}

${ }^{\mathrm{z}}$ Bulk density was calculated by weighing air-dried samples in a container with a known volume. Mulch weight in containers shows the average weight of a 2 -inch $(5.08 \mathrm{~cm})$ layer of mulch in $1.7-\mathrm{L}(0.45 \mathrm{gal})$ nursery containers used in bioassay experiments; $1 \mathrm{~g} \cdot \mathrm{cm}^{-3}=62.4274 \mathrm{lb} / \mathrm{ft}^{3}, \mathrm{l} \mathrm{g}=0.0353 \mathrm{oz}$.

${ }^{\mathrm{y}}$ Average mulch surface area was calculated using mulch weight and individual mulch particles using ImageJ software (Schneider et al., 2012); $1 \mathrm{~cm}^{2}=0.1550 \mathrm{inch}^{2}$.

${ }^{\mathrm{x}}$ Void space shows average percentage of air, water, and solid in a given volume of mulch using a modified volume of voids calculation (Akdeniz et al., 2011; Simmons and Derr, 2007).

${ }^{\mathrm{w}}$ Means within a column followed by the same letter are not significantly different according to Fisher's protected least significant difference $(P<0.05)$

Table 5. Lignin, cellulose, and hemicellulose concentration of hard wood, pine bark, and pine straw mulch.

\begin{tabular}{lccc}
\hline & Lignin & Cellulose & Hemicellulose \\
\cline { 2 - 4 } & & Composition (\%) & \\
\hline Hardwood $^{\mathrm{z}}$ & 30 & 48 & 22 \\
Pine bark $^{\mathrm{y}}$ & 45 & 25 & 15 \\
Pine straw & 38 & 43 & 22 \\
\hline
\end{tabular}

${ }^{\mathrm{z}}$ Derived from average of listed values (Pereira et al., 2013).

${ }^{y}$ Derived from average of listed values (Valentin et al., 2010).

${ }^{\mathrm{x}}$ Derived from average of listed values (Howard, 1973).

to less adsorption with this mulch. These results would agree with previous reports by Benoit et al. (2008), in that herbicide adsorption cannot be predicted based on chemical properties only, but that physical properties also play a significant role.

Results from these studies demonstrate commonly used preemergence herbicides in landscapes or nurseries are bound in organic mulch materials. Only $10 \%$ to $30 \%$ of the herbicide that was applied reached the substrate surface, at least initially following only $\approx 1.5$ inches of irrigation over a short period, which is similar to previous findings (Banks and Robinson, 1982; Crutchfield et al., 1986; Dao, 1991). Although it is possible that herbicides leached downward beneath the 1-inch depth used for chemical analysis, this would be unlikely given that these herbicides are generally adsorbed tightly to PB substrates (Stewart et al., 2019). Only 1.5 inches of irrigation was applied over a short 3$\mathrm{d}$ period in this study, and none of the evaluated herbicides would be expected to leach deeper than based on previous reports (Derr et al., 2015; Jhala and Singh, 2012).

Herbicides generally tend to adsorb more tightly to mulch materials or soils with higher organic matter with up to five times greater adsorption being reported in mulches compared with field soils in some studies (Hodges and Talbert, 1990). Most previous research on herbicide movement or adsorption by mulch has been conducted in agronomic crops with lower levels of plant residue and with herbicides with higher solubility and $K_{o c}$ than were evaluated in this experiment. Even among herbicides that would have a greater tendency to move through a mulch material, high levels are usually retained in the mulch or residue. For example, up to $60 \%$ of applied metribuzin was intercepted by a straw mulch (Banks and Robinson, 1982), whereas $80 \%$ of metolachlor was intercepted by wheat straw immediately after application (Crutchfield et al., 1986). Metribuzin has a $\mathrm{K}_{\mathrm{oc}}$ of $60 \mathrm{~mL} \cdot \mathrm{g}^{-1}$ and metolachlor of $200 \mathrm{~mL} \cdot \mathrm{g}^{-1}$, which would be similar to dimethenamid-P (55 to 125 $\left.\mathrm{mL} \cdot \mathrm{g}^{-1}\right)$ but significantly less than any other herbicides evaluated in this study (Table 2) (Senseman, 2007). These previous reports with metribuzin and metolachlor are in agreement with chemical assay data reported here in which $66 \%$ of applied dimethenamid$\mathrm{P}$ was recovered under $\mathrm{PB}$.
Although adsorption absorption to mulch is a rapid process, desorption is typically a slow process occurring over weeks or months depending on mulch degradation, herbicide half-life and adsorption coefficients, and environmental factors, including rainfall and irrigation (Aslam et al., 2013; Hodges and Talbert, 1990; Huang et al., 2006; Selim and Zhu, 2005). As most herbicide labels indicate that 0.25 to 0.5 inch of irrigation is needed to water in herbicides following application, it is possible additional irrigation will be needed with some preemergence herbicides applied to mulched nursery containers or landscape beds. Previous studies have reported that increased irrigation or rainfall may not result in significantly greater weed control or herbicide concentrations below mulch materials with herbicides with low solubility, such as pendimethalin (Banks and Robinson, 1982; Saha et al., 2019). Conversely, higher irrigation is likely to cause greater mobility and downward leaching of more water-soluble herbicides such as atrazine, which may also influence efficacy (Bauman and Ross, 1983; Ghadiri et al., 1984).

It is also important to note that these studies were conducted on commercially available mulch materials, and although the mulch was used immediately after procuring, the exact age of the material after harvesting was unknown. As herbicides degrade in a landscape or nursery environment, particle sizes will change, as will chemical composition (Duryea et al., 1999). Increased adsorption has been noted in plant residues and wood-derived mulches, thus additional research may be needed to determine the influence of aged mulch on herbicide efficacy over time (Aslam et al., 2013; Dao, 1991). Although only a small portion of the total herbicide applied reached the substrate surface in mulched containers, in most instances commercially acceptable $(>80 \%)$ weed control was observed over the 4 -week evaluation period even though mulch was removed and was not available to aid in weed suppression. Determining dose response relationships of each of these three weed species with the three different herbicidal products was beyond the scope of this experiment, but it is evident that these herbicides are relatively active on these weeds at low rates. It is unknown, however, how efficacy would be affected over 
a longer period and or if seeds were sown on multiple dates.

Although these data show a high degree of herbicide binding to mulch, use of preemergence herbicides on mulched containers or landscape beds could still offer significant advantages. In many cases, weed germination and growth significantly increase when seeds are placed on top of mulch compared with seeds below mulch (Richardson et al., 2008; Saha et al., 2019). Therefore, an herbicide that is retained in the mulch layer may be available to prevent growth of weed seeds deposited on top of the mulch layer. Weed control from these different herbicide + mulch combinations (when mulch was left on the substrate surface) was not determined in the current study, but these combinations have been shown to provide season-long weed control in previous studies (Bartley et al., 2017; Saha et al., 2019; Somireddy, 2012). Similarly, in studies with crop residues, satisfactory weed control has often been reported even in cases in which most of the herbicide was intercepted by surface residue (Crutchfield et al., 1986; Ghadiri et al., 1984). This is primarily because weed control usually increases as mulch depth increases, regardless of weed seed placement due to the inhibitory effects of mulch on weed germination and growth (Crutchfield et al., 1986; Chalker-Scott, 2007; Ghadiri et al., 1984; Marble et al., 2015a, 2015b). Although these data show that PS may adsorb less herbicide than $\mathrm{PB}$ or HW, more data are needed to evaluate long-term control with these combinations in a variety of environments. Future research also should determine if herbicide application volume has any influence on mulch interception, and what role herbicide formulation/application method (granular vs. spray-applied) has on efficacy, movement, and activation. Cost, aesthetics, availability, durability, and consumer acceptance also should be considered when evaluating mulch either with or without the use of preemergence herbicides.

\section{Literature cited}

Ahmad, R., R.S. Kookana, A.M. Alston, and J.O. Skjemstad. 2001. The nature of soil organic matter affects sorption of pesticides 1 . Relationships with carbon chemistry as de- termined by 13C-CPMAS NMR spectroscopy. Environ. Sci. Technol. 35:878-884.

Akdeniz, N., K.A. Jannie, and I.A. Salnikov. 2011. Biofilter performance of pine nuggets and lava rock as media. Bioresour. Technol. 102:4974-4980.

Aslam, S., P. Garnier, C. Rumpel, S.E. Parent, and P. Benoit. 2013. Adsorption and desorption behavior of selected pesticides as influenced by decomposition of maize mulch. Chemosphere 91:1447-1455.

Banks, P.A. and E.L. Robinson. 1982. The influence of straw mulch on the soil reception and persistence of metribuzin. Weed Sci. 30:164-168.

Banks, P.A. and E.L. Robinson. 1984. The fate of oryzalin applied to strawmulched and nonmulched soils. Weed Sci. 32:269-272.

Banks, P.A. and E.L. Robinson. 1986. Soil reception and activity of acetochlor, alachlor, and metolachlor as affected by wheat (Triticum aestivum) straw and irrigation. Weed Sci. 34:607-611.

Bartley, P.C., III, G.R. Wehtje, A.M. Murphy, W.G. Foshee, III, and C.H. Gilliam. 2017. Mulch type and depth influences control of three major weed species in nursery container production. HortTechnology 27:465-471.

Bauman, T.T. and M.A. Ross. 1983. Effect of three tillage systems on the persistence of atrazine. Weed Sci. 31:423-426.

Benoit, P., I. Madrigal, C.M. Preston, C. Chenu, and E. Barriuso. 2008. Sorption and desorption of non-ionic herbicides onto particulate organic matter from surface soils under different land uses. Eur. J. Soil Sci. 59:178-189.

Brás, I.P., L. Santos, and A. Alves. 1999. Organochlorine pesticide removal by pine bark sorption. Environ. Sci. Technol. 33:631-634.

Buhler, D.D. 1992. Population dynamics and control of annual weeds in corn $(Z e a$ mays) as influenced by tillage systems. Weed Sci. 40:241-248.

Case, L.T., H.M. Mathers, and N. Tuttle. 2002. Herbicide-treated mulches for ornamental weed control. Proc. Northeastern Weed Sci. Soc. 56:72.

Case, L.T., H.M. Mathers, and A.F. Sensesac. 2005. A review of weed control practices in container nurseries. HortTechnology 15:535-545.

Chalker-Scott, L. 2007. Impact of mulches on landscape plants and the environment-A review. J. Environ. Hort. 25:239-249.
Chauhan, B.S. and S.B. Abugho. 2012. Interaction of rice residue and pre herbicides on emergence and biomass of four weed species. Weed Technol. 26:627-632.

Crown, L., D. Sefcik, and L. Warfield. 2013. NIST handbook 133. 4th ed. U.S. Dept. Commerce, Washington, DC.

Crutchfield, D.A., G.A. Wicks, and O.C. Burnside. 1986. Effect of winter wheat (Triticum aestioum) straw mulch level on weed control. Weed Sci. 34:110-114.

Dao, T.H. 1991. Field decay of wheat straw and its effects on metribuzin and s-ethyl metribuzin sorption and elution from crop residues. J. Environ. Qual. 20:203-208.

Derr, J., L. Robertson, and E. Watson. 2015. Leaching behavior of two pendimethalin formulations in a soilless growing medium. Weed Sci. 63:555-560.

Duryea, M.L., R.J. English, and L.A. Hermansen. 1999. A comparison of landscape mulches. J. Arboric. 25:88-97.

Ghadiri, H., P.J. Shea, and G.A. Wicks. 1984. Interception and retention of atrazine by wheat (Triticum aestivum L.) stubble. Weed Sci. 32:24-27.

Hodges, L. and R.E. Talbert. 1990. Adsorption of the herbicides diruon, terbacil, and simazine to blueberry mulches. HortScience 25:401-402.

Howard, E. 1973. Properties of southern pine needles. Wood Sci. 5:281-286.

Huang, X., A. Massoudieh, and T.M. Young. 2006. Measured and predicted herbicide removal by mulch. J. Environ. Eng. 132:918-925.

Jhala, A.J. and M. Singh. 2012. Leaching of indaziflam compared with residual herbicides commonly used in Florida citrus. Weed Technol. 26:602-607.

Johnson, B.J. 1997. Sequential applications of preemergence and postemergence herbicides for large crabgrass (Digitaria sanguinalis) control in tall fescue (Festuca arundinacea) turf. Weed Technol. 11:693-697.

Knight, P.R., C.H. Gilliam, S.L. File, and D. Reynold. 2001. Mulches reduce herbicide loss in the landscape. South. Nursery Assn. Res. Conf. 46:461-463.

Locke, M.A. and C.T. Bryson. 1997. Herbicide-soil interactions in reduce tillage and plant residue management systems. Weed Sci. 45:307-320.

Marble, S.C. 2015. Herbicide and mulch interactions: A review of the literature and implications for the landscape maintenance industry. Weed Technol. 29:341-349. 
Marble, S.C., C.H. Gilliam, G.R. Wehtje, A.J. Van Hoogmoed, and C. Palmer. 2011. Early postemergence control of spotted spurge in container production. J. Environ. Hort. 29:29-34.

Marble, S.C., A.K. Koeser, and G. Hasing. 2015a. A review of weed control practices in landscape planting beds: Part 1-Nonchemical methods. HortScience 50:851856.

Marble, S.C., A.K. Koeser, and G. Hasing. $2015 \mathrm{~b}$. A review of weed control practices in landscape planting beds: Part 2-Chemical methods. HortScience 50:857-862.

Mathers, H. and E. Ozkan. 2001. Herbicide treated mulches. Nursery Mgt Production 17:61-64.

Mathers, H.M. and L.T. Case. 2010. Microencapsulated herbicide-treated bark mulches for nursery container weed control. Weed Technol. 24:529-537.

Mersie, W., C.A. Seybold, J. Wu, and C. McNamee. 2006. Atrazine and metolachlor sorption to switchgrass residues. Commun. Soil Sci. Plant Anal. 37:3-4.

Neal, J., J.C. Chong, and J. WilliamsWoodward. 2017. Southeastern US pest control guide for nursery crops and landscape plantings. 18 June 2019. <https:// content.ces.ncsu.edu/southeastern-uspest-control-guide-for-nursery-cropsand- landscape-plantings $>$.

Pereira, B.L.C., A.D.C.O. Carneiro, A. Marcia, J.L. Colodette, A. Oliveira, and M.P.F. Fontes. 2013. Influence of chemical composition of eucalyptus wood on gravimetric yield and charcoal properties. BioResources 8:4574-4592.

Powrie, W. 2014. Soil mechanics. 3rd ed. CRC Press, London, U.K.

Richardson, B., C.H. Gilliam, G.B. Fain, and G. Wehtje. 2008. Container nursery weed control with pine bark mini-nuggets. J. Environ. Hort. 26:144-148.

Riggle, B.D. and D. Penner. 1992. Kraft lignin adsorption of metribuzin as a controlledrelease function evaluation. J. Agr. Food Chem. 40:1710-1712.
Robertson, L. and J.F. Derr. 2017. Dimethenamid persistence and leaching potential in a soilless mix. J. Environ. Hort. 35:99-102.

Saha, D., S.C. Marble, B.J. Pearson, H.E. Perez, G.E. MacDonald, and D.C. Odero. 2019. Mulch type and depth, herbicide formulation, and post-application irrigation volume influence on control of common landscape weed species. HortTechnology 29:65-77.

Schneider, C.A., W.S. Rasband, and K.W. Eliceiri. 2012. NIH image to ImageJ: 25 years of image analysis. Nat. Methods 9:671-675.

Selim, H.M., L. Zhou, and H. Zhu. 2003. Herbicide retention in soil as affected by sugarcane mulch residue. J. Environ. Qual. 32:1445-1454.

Selim, H.M. and H. Zhu. 2005. Atrazine sorption-desorption hysteresis by sugarcane mulch residue. J. Environ. Qual. 34:325-335.

Senseman, S.A. 2007. Herbicide handbook. 9th ed. Weed Sci. Soc. Amer., Lawrence, KS.

Simmons, D.R. and J.F. Derr. 2007. Pendimethalin movement through pine bark compared to field soil. Weed Technol. 21:873-876.

Somireddy, U. 2012. Effect of herbicideorganic mulch combinations on weed control and herbicide persistence. Ohio State Univ., Columbus, Ph.D. Diss.

Stewart, C., S.C. Marble, B.E. Jackson, B. Pearson, C. Wilson, and D.K. Lauer. 2019. Influence of pine bark substrate age on performance and leaching of nursery preemergence herbicides. HortScience 54:896-902.

Teasdale, J.R. and C.L. Mohler. 2000. The quantitative relationship between weed emergence and the physical properties of mulches. Weed Sci. 48:385392.
U.S. Environmental Protection Agency. 2010. Indaziflam pesticide fact sheet. 7 Apr. 2019. <https://www3.epa.gov/ pesticides/chem_search/reg_actions/ registration/fs_PC- 080818_26-Jul-10. pdf $>$.

U.S. Environmental Protection Agency. 2016. Method 3540C, Soxhlet extraction. 4 June 2018. <https://www.epa. gov/sites/production/files/2015-12/ documents/3540c.pdf>.

U.S. Environmental Protection Agency. 2018a. Method 8270E, Semivolatile organic compounds by gas chromatography/ mass spectrometry 2018. 15 July 2018. <https://www.epa.gov/sites/production/ files /201704/documents / method_ 8260d_update_i _final_03-13-2017_0. $\mathrm{pdf}>$.

U.S. Environmental Protection Agency. 2018b. Method 8321B, Solvent-extractable nonvolatile compounds by high-performance liquid chromatography/thermospray /mass spectrometry (HPLC/TC/MS) or ultraviolet (UV) detection 2007. 12 Oct. 2018. <https://www.epa.gov/sites/production/ files/2015-12/documents/832lb.pdf .

Valentin, L., B. Kluczek-Turpeinen, S. Willfor, J. Hemming, A. Hatakka, K. Steffen, and M. Tuomela. 2010. Scots pine (Pinus sylvestris) bark composition and degradation by fungi: Potential substrate for bioremediation. Bioresour. Technol. 101:2203-2209.

Weber, J.B. 1990. Behavior of dinitroaniline herbicides in soils. Weed Technol. 4:394-406

Wilen, C.A. and C.L. Elmore. 2007. Weed management in landscapes. Univ. California Pest Notes No. 7441.

Wilson, C., T. Whitwell, and M.B. Riley. 1996. Detection and dissipation of isoxaben and trifluralin in containerized plant nursery runoff water. Weed Sci. 44:683-688. 